\title{
Chinese Investments in Brazil: Economic Diplomacy in Bilateral Relations
}

\author{
Virginia Soledad Busilli* \\ María Belén Jaime**
}

\begin{abstract}
The People's Republic of China has consolidated its status as a great power and strengthened its presence in different regions of the planet. In accordance with its economic development strategy, Beijing's growing bond with Latin America is part of China's need to guarantee access to raw materials and energy resources. In this framework and through economic diplomacy, China has strengthened its trade relations, as well as loans and investments in most of the region's countries. Brazil is an example of this relationship pattern, as one of China's most important partners and top investment destination in Latin America. It became Beijing's top commercial partner in 2012. This paper will analyse the composition and evolution of Chinese foreign direct investment (FDI) in Brazil between the years of 2004 and 2020. In order to do so, we will study the main projects carried out by the country, as well as the characteristics of the Chinese companies (state or non-state) that participated in the process, in order to understand their most important features. Likewise, we will analyse the articulation of the Chinese FDI with its trade flows. We will start from the premise that Chinese investments in Brazil are directly linked to Beijing's strategic interests, while at the same time guided by market logics that try to maximise profits. In this vein, within the framework of the 'going out strategy', state companies play a fundamental role.
\end{abstract}

Keywords: Latin America, China, economic diplomacy, FDI, strategic interests.

\section{Introduction}

After decades of a process of economic reforms and opening-up, since the late 1990s the People's Republic of China has implemented the 'going out strategy', encouraging national Chinese companies to go abroad in search of investment opportunities (Wang 2016; Svampa and Slipak 2015).

\footnotetext{
* Scientific and Technological Center of the National Council for Scientific and Technical Research (CONICET), Cordoba-Cordoba, Argentina; virginia.busilli@gmail.com. ORCiD 0000-0002-6305-8010.

** Catholic University of Cordoba, Cordoba-Cordoba, Argentina; mariabelenjabi1@hotmail.com. ORCiD 0000-0001-8157-4185.
} 
The main driving force behind this Foreign Direct Investment (hereinafter FDI) -defined by UNCTAD and the IMF as a movement of capital from one nationality to another, with a lasting purpose and with participation interests of a company (IMF 2004) - has been the enormous amount of international reserves that China accumulated since the beginning of the century, that were mainly used to acquire North American debt (Wang 2016). The 2008 global financial crisis, which led to a retreat of the great western powers, helped to strengthen China's image as a global power. Beijing managed to grow at $8.7 \%$ while the rest of the world experienced a strong contraction of the Gross Domestic Product (GDP), which ranged between $0.8 \%$ and $3.2 \%$. This was possible due to an economic stimulus package, accompanied by a formidable credit expansion (ECLAC 2010).

After the crisis, a new consensus was created in the People's Republic of China on the need to invest in new foreign assets, generating a significant increase in FDI and international aid (Wang 2016). As a result, China's weight in the world economy strengthened and its trade and financial policies began to expand into new regions. This new boost in Chinese FDI cannot be understood outside the framework of the country's economic growth and consolidation of the reform process. After decades of double-digit economic growth rates, China became the world's largest exporter and second importer in 2007, later establishing itself as the second global economy (Li 2017). That way, Beijing has become a true global trader importing raw materials, energy and intermediate products from the developing world, and exporting manufactured products to the developed world (Liang 2019). This internal process placed China as one of the world's main consumers of energy, aluminium, copper, oil, among others at the beginning of the century (Svampa and Slipak 2015).

Along these lines, China's interest in Latin America has grown significantly since the beginning of the century as part of the 'going out strategy' and the internationalization of Beijing's development model (Wise and Chonn Ching 2018). Said model commits the Asian country to economic complementarity. The region is rich in resources that Beijing considers strategic for its energy and food security, such as copper, crude oil, iron ore and soybeans, produced in countries such as Argentina, Brazil, Venezuela, Chile and Peru.

Authors such as Harry Geoff Broadman (2007), Wenjie Cheng and Heiwai Tang (2014) argue that by observing feedback, there are positive links between the pattern of trade and investment. This correlation can also be found in Beijing's relationship patterns with Latin America. On the one hand, Chinese FDI in infrastructure sectors promotes an improvement in trade flows; on the other, FDI is also carried out in the areas in which China concentrates its imports. Finally, investment in these strategic sectors is mostly led by Chinese state-owned companies. More recently, authors such as Myers (2014), Wenyuan Wu (2020), Gabriel Barros (2020) and Tulio Cariello (2019) expand their analysis by stating that these companies are also driven by a market logic and seek profitable markets to invest in Latin America.

In this scenario, Brazil occupies a fundamental place in Chinese's strategy in Latin America. In 2004, the strategic association was relaunched. It represented a turning point 
for the countries of the region. That same year, the strategic association with Argentina, Chile and Cuba was added. This political approach was translated into an economic one.

In line with Ana L. Abeliansky and Inmaculada Martínez-Zarzoso (2019), a positive relationship between trade and investment is observed: China exports more to countries where it has active FDI. Likewise, higher FDI flows are associated with a greater increase in Chinese exports and imports. This happens in the China-Brazil relationship. While in 2004 Beijing was Brazil's third destination with a 6.2\% share of total exports, in 2009 (according to ALADI databases) China became the first Brazilian export destination, worth US $\$ 20191 \mathrm{~m}$ (13.2\% of total exports that year). In 2012, Brazil imported Chinese products worth US $\$ 36465 \mathrm{~m}$ (15.6\% of total exports in 2009), compared to the US\$33 $842 \mathrm{~m}$ it imported from the United States (14.5\%). From then on, China became Brazil's first commercial partner and main destination for exports and origin of imports (ALADI 2020). On the other hand, Brazil is the main recipient of Chinese FDI in the region, capturing $35.6 \%$ of the total FDI originating from China.

From that observation, a series of questions arise: What interests led the Asian giant to approach the Latin American region? What place does Brazil occupy within that strategic move? Regarding investment, what are the characteristics of Chinese FDI in Latin America? Are they similar to those registered in Brazil? What companies led the main investment projects carried out in the region? In what sectors? How are trade and investment patterns connected? Do they respond to Beijing's strategic interests?

This paper aims to analyse what were the main characteristics of Chinese FDI flows in Brazil between 2004 and 2020. In order to do so, we will divide the research work into two parts. The first part will be devoted to theoretical considerations, where we will address the concept of economic diplomacy and focus on China's interests in the region and on the place that Brazil occupies in Beijing's strategic calculations. The second will be devoted to the analysis of the characteristics of Chinese FDI in Latin America, covering its main recipient countries and the sectors it is destined to. Lastly, we will study Chinese FDI in Brazil, focusing on the target sectors and on the characteristics of the Chinese companies (state or private) that carry out such investment projects, and how they relate to trade flows to determine if they are linked to China's strategic interests.

We will start from the premise that Chinese investments in Brazil (between 2004 and 2020) are twofold in nature: they focus on meeting the demand for food and energy in the medium and long term while at the same time seeking profitable markets. Regarding the first statement and in terms of economic diplomacy, we state that the investments are mostly carried out by state-owned companies and articulated with trade to achieve the strategic objectives of Beijing's food and energy security. In this vein, investment flows work like a "carrot" by offering Brazil investments in sectors in which the country shows deficiencies and needs long-term improvements (like infrastructure and energy supply). 


\section{An approach to the concept of economic diplomacy}

From a theoretical perspective, our work is part of the analysis of economic diplomacy. Defining the concept has become a task of increasing complexity, since a multiplicity of actors, levels, processes, instruments, and results that are part of its creation and framework intervene.

It is possible to identify two great approaches to economic diplomacy. The first focuses on analysing economic diplomacy through actions and processes. Authors such as Kejin Zhao (2011), who follows that approach, define it as peaceful activities carried out by a state or group of states. Christopher Hill (2016), for his part, considers economic diplomacy as the need to promote economic prosperity through foreign economic policies. For Nicholas Bayne and Stephen Woolcock (2017), economic diplomacy is a decision-making process and for Kishan Rana (2013), foreign policy objectives are accommodated in the decision-making process in the domestic sphere and in the institutions that play a role in it.

The second, to which this research work subscribes, pays special attention to economic resources, means and instruments. Geoff Berridge and Alan James (2003) define economic diplomacy as the use of economic resources, both in terms of incentives and sanctions, in the pursuit of a specific foreign policy objective (Zhang 2017). This interpretation is close to the concept of economic statecraft. For Baldwin (1985), it can be understood as the manipulation, by a state, of economic activities for strategic purposes. This perspective speaks closely to the international relations' realist paradigm, in which authors such as Robert Gilpin (1990) define economic power as the basis of political power.

It was previously mentioned that the economic policy of power is the ability of a state to get another actor to respond to its strategic interests, through economic means (Norris 2010). Yet, how exactly does a state make another state respond to its interests? In order to do so, there are two main instruments: the "stick" or the "carrots". The first refers to sanctions or punishments, and the second, to the incentives that one state can use to persuade another. Along these lines, James Reilly (2013) argues that the economic statecraft is developed through three main areas, namely 1) the provision of capital through foreign aid or foreign investment; 2) the expansion of trade through preferential agreements, and 3) monetary policies.

In the case of China, William Norris (2010) argues that Beijing has sought development and has incorporated the economic sphere into what he calls its grand strategy. The latter can be defined as the combination of military, political, and economic means through which a state seeks to secure its national interests (Goldstein 2005). That way, the economic statecraft 'reflects the intrinsic relationship between the economic and political spheres, where the former is placed at the service of the latter, becoming an analysis of the economic [sphere] as a tool of the political' (Baldwin 1985).

For Norris (2010), the economy and security are linked in China in three different ways. First, international economic relations are essential for long-term economic development. Beijing needs a peaceful environment to sustain its economic growth rates and consolidate its global power. In this vein, the special emphasis on highlighting the peaceful 
nature of their rise is understandable. Second, the economic factor within the main Chinese strategy is legitimating the regime. The highest national interest is to maintain the CCP's control over China. Finally, it seeks to design a strategic international environment to maximize its national interests.

At the beginning of the 21 st century, China was faced with the need to internationalise its development strategy to compensate for its deficit of natural resources to sustain and feed its population, as well as to supply its exporting economic model (Wise and Chonn Ching 2018). These reasons led Beijing to approach other regions, such as Latin America, both in terms of trade and investment. Likewise, the region has the potential to consume Chinese exports and, therefore, promote their diversification (Busilli 2019: Li 2007).

Following the line of analysis of Wei Liang (2019), Latin America gains relevance in Beijing's strategic calculations in different areas. Firstly, it becomes relevant in terms of strengthening energy security and the supply of commodities. Since its arrival in the region, Beijing acted with special caution not to generate tension with the United States, highlighting its interest in diversifying its sources of supply. For Bernal-Meza and Li (2020), this caused a trade deterioration for Latin America and new challenges for its economic development.

Secondly, China seeks to integrate the Latin American region into the Belt and Road Initiative (BRI). Since the arrival of Xi Jinping, Chinese foreign policy has become more global and assertive (Li and Taube 2019; Greitens 2013; Delage 2015). One example thereof is the BRI, which became the flagship project of the Chinese president Xi Jinping and his most ambitious proposal. Created in 2013, it is the most important infrastructure project in the world. Its objective is to connect Asia, Europe and Africa through Central Asia and South Asia. In the Special Declaration of Santiago of the II Ministerial Meeting of the CELAC-China Forum on the Belt and Road Initiative in 2018, Latin America was considered the initiative's 'natural extension' by the Chinese government. The region has significant infrastructure shortcomings, rendering the Initiative an interesting option. On the other hand, the main reservations to join it lie in the use of Chinese labour, as well as the bidding of Chinese companies for the execution of projects (Johnson 2016).

Thirdly, Latin America's relevance refers to the Chinese objective of intensifying its relations with it through the institutionalization of ties, both at the bilateral and regional levels. In this sense, China's establishing of strategic associations with its main commercial partners stands out as a way of categorizing and prioritizing links between them. CEL$\mathrm{AC}$ became the main regional meeting place, without the presence of the United States (Ramón-Berjano, Malena and Velloso 2015).

Fourthly, the deepening of the reforms that began in the 1990s and the launching of the 'going out strategy' drove Chinese companies abroad, seeking to make them increasingly competitive according to the market logic. At the same time, these state-owned companies focused on strategic sectors for Beijing, responding to the objectives of the five-year plans designed by the government (Wu 2020). 
Lastly, the Taiwan issue. China has only one requirement for the establishment of bilateral and multilateral relations in the region: the one-China principle. It should be noted that, of the 17 countries that formally recognize Taiwan, nine of them are located in Latin America, namely Belize, Haiti, Nicaragua, Saint Kitts and Nevis, Saint Vincent and the Grenadines, Dominican Republic, Guatemala, Paraguay, Honduras and Santa Lucy. In terms of economic statecraft, this section is enlightening. By way of 'sticks' Beijing has restricted access to its market and loans for those countries that do not recognize the principle of one China and the People's Republic of China (PRC) as the legitimate representative of the Chinese people (Liang 2019). Given our study objectives, the present work will focus on the first and fourth postulates.

\section{Chinese FDI in the region}

Foreign direct investment flows have been a key and indispensable factor for the consolidation of the different development models, both at the national and regional levels in Latin America (Orozco Suárez 2018). During the 20th century, these flows came mainly from Europe and the United States, but from the 21 st century and more specifically from 2010 on, foreign direct investment acquired an unusual and recurrent Chinese presence (ECLAC 2018).

China registered two types of investment at the beginning of the 21st century with the 'going out strategy' in place since the late 1990s. These were, respectively, FDI from Chinese multinational companies directed towards developed countries, producers of medium and high technology goods and services, and FDI from producers of medium and low technology goods, trading companies and extractive companies with investments located mainly in less developed countries (Avedaño Miranda 2014).

The 2008 global financial crisis hit developed countries especially hard, hence allowing Chinese companies to enter markets that were formerly hostile, strengthening Beijing's image as a global power and making the country increasingly attractive in terms of financial options.

The exponential growth of Chinese FDI in 2010 is due to two large acquisitions of Chinese state companies in the oil industry. ${ }^{1}$ This trend can be seen in Figure 1 above. In 2017, Chinese FDI was US \$13 650m and, despite registering lower flows of investment when compared to previous years, Beijing established itself as the main investor in Latin America, followed by the European Union and the United States (ECLAC 2018).

In line with what we have just explained, from 2004 to 2019, we can identify four countries as recipients of the FDI flows from China: Brazil (35.9\%), Argentina (16\%), Venezuela (15\%), and Peru (14,7\%). The energy sector was the sector that received the largest investment flows in Brazil, Argentina and Venezuela; while in Peru the metals sector stood out from the remaining ones (AEI 2021). 


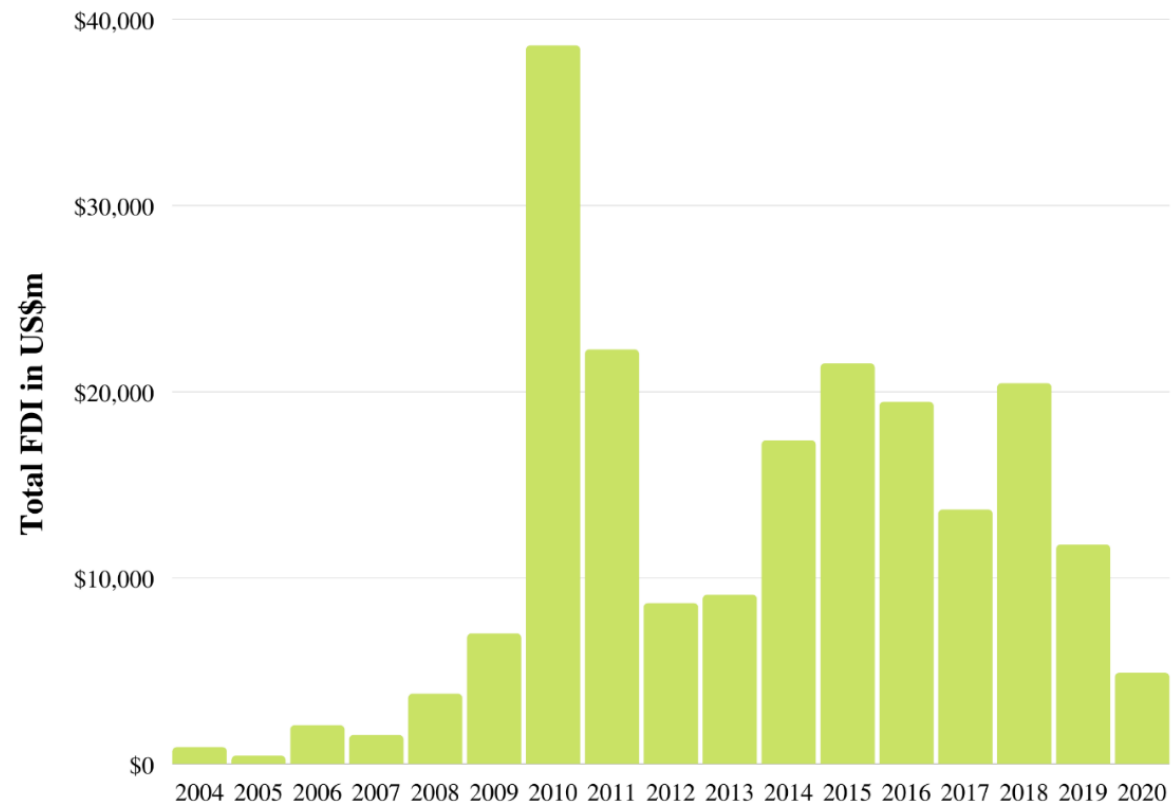

Source: Elaborated by the authors with data obtained from AEI (2021) and ECLAC (2005).

\section{The China-Brazil partnership}

As China expanded its investment and trade flows, governments reacted differently. Conflicting opinions aroused, especially in Latin America, rendering it difficult for Latin America to achieve a more homogeneous and articulated approach towards China, which would allow weighing up the asymmetry to design joint strategies. While many governments welcomed Chinese capital, others were more cautious in that sense (Wu 2020; Cariello 2019).

Brazil was the first developing country to sign a strategic partnership with the Asian giant, in 1993, and political and economic ties were renewed at the beginning of the century. The growth of Chinese interest in the South American country coincided with the election of Luiz Inácio Lula da Silva as president in January 2003, which produced an important change in Brazilian foreign policy. In his two terms (2003-2006 and 2007-2010), Lula was characterized by a multipolar, multilateral and internationalist vision - for some, the result of the South-South cooperation perspective (Altemani de Oliveira 2006). The foreign policy of the new president maintained an important autonomist profile, defined by Tullo Vigevani and Gabriel Cepaluni $(2007 ; 2009)$ as 'autonomy through diversification. It was characterized by adherence to international standards through South-South alliances, including regional ones, and agreements with non-traditional partners (China, 
Asia Pacific, Africa, Eastern Europe, the Middle East, etc.), with the aim of reducing asymmetry with the most powerful countries and increasing Brazil's negotiating capacity.

Since Lula's arrival, bilateral relations gained special momentum, which was functional to Brazil's foreign policy objectives of strengthening its influence on a global scale and influencing the rules of the international trade game (Busilli 2019).

In the framework of Hu Jintao's historic tour of the region in 2004, the Sino-Brazilian High-Level Commission for Agreement and Cooperation (COSBAN) was created and became the highest instance of permanent dialogue and bilateral cooperation between the two countries. In November of the same year, Brazil recognized China as a market economy, a fact that represents a clear example of economic statecraft. For a country to be considered a market economy, it must have an open capital market, not discriminate in its trade, and have ample facilities for foreign investment. China did not meet these requirements at the time of its accession (Oviedo 2005), but COSBAN provided it with the possibility of extending the established deadline (normally, of fifteen years), thus obtaining individual recognition from the countries. For China, this was a major diplomatic success. For Brazil, this translated into a long-term political gesture in exchange for promises of trade and investment. Another important point is that it renounced the application of a valuable commercial regulation instrument such as anti-dumping measures, since from that moment on, it had to refer to the prices of the People's Republic of China instead of third countries with higher reference values.

Brazil's action inaugurated a new chapter in the region, since shortly thereafter Argentina and Chile also recognized China as a market economy. That way, China's comprehensive strategy towards Latin America was strengthened. Said strategy sought to expand its economic opportunities and, at the same time, gain international recognition and reinforce its status as a responsible power (Medeiros 2009: 87).

As we have seen, the growth of FDI in Brazil is not an isolated event but responds to a logic of global expansion of Chinese investments. Thus, while in 2006 Chinese FDI in the world reached US\$73b, in 2019 its numbers climbed to US\$3tn, placing China as the second source of FDI in the world (Wachholz 2019).

The United States has traditionally been the main investor for Brazil, followed by European countries such as the Netherlands, Germany, and France. Indeed, due to the growing arrival of Chinese capital, they continue to occupy an important place in terms of Brazilian FDI strategic partners (ECLAC 2019). ${ }^{2}$

\section{The historical evolution of Chinese FDI in Brazil}

The large Chinese investments in Brazil are a recent fact whose expansion dates from the second decade of the 21 st century. If we go back to the mid-1990s, we can see that Chinese capital in the Latin American country was not relevant. As we can see in Figure 2, the Chinese FDI prior to 2009 was low. Indeed, only during 2005 and 2006 was there a slight rise when it climbed to US\$670m and US\$1630m respectively, after the relaunch of the bilateral strategic association in 2004. But it was not until 2010, when investment in 21 
projects was announced, that Chinese FDI marked a turning point compared to previous years, reaching US $\$ 13$ 890m (ECLAC 2019). From then on, the Asian giant was among the main investors in the country.

Figure 2 below shows the historical evolution of Chinese FDI in Brazil. In 2011 and until mid-2012, 32 additional investment projects were announced. During these years, Chinese FDI reached US $\$ 7720 \mathrm{~m}$ and US $\$ 2990 \mathrm{~m}$ respectively, signalling a new phase in the bilateral economic relationship (CBBC 2013). A year later, in 2017, the maximum values of Chinese FDI were registered: US\$14 080m. That same year, China replaced the United States as the first source of FDI. While Washington regained the podium in late 2017 and in early 2018, Beijing ranked second throughout the end of the study period, displacing Germany and France to rank third and fourth, respectively (AEI 2021).

Figure 2. Historical evolution of Chinese FDI in Brazil (1995-2020)

$\$ 15,000$

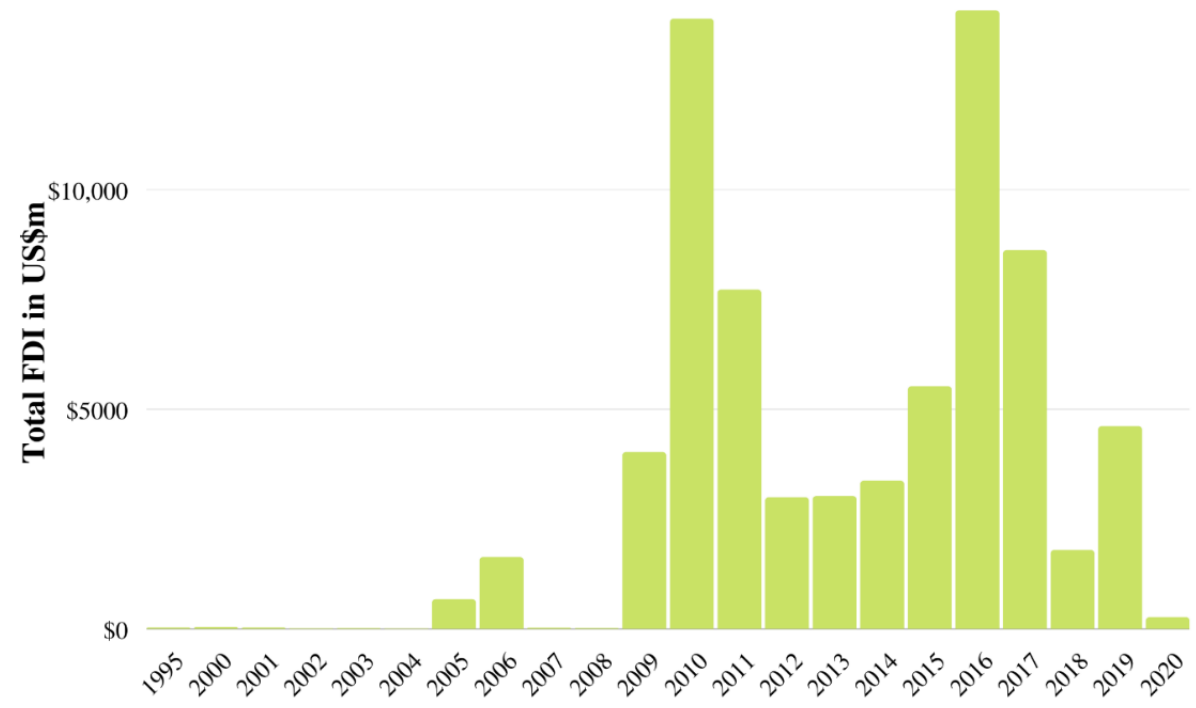

Source: Elaborated by the authors with data obtained from the Central Bank of Brazil (2020) and AEI (2021).

According to the analysis laid out by Tullo Cariello (2019), Chinese FDI can be divided into four phases. The first phase took place until 2010 and focused on the production of strategic raw materials for China (especially soybeans, crude oil, and iron ore). During this stage, control was focused on key stages of the supply chains of products exported to China. The FDI received between the late 1990s and 2010 reached US\$20 372m (Central Bank of Brazil 2020; AEI 2021).

The second, between 2011 and 2013, was the period during which Chinese FDI was aimed at exploring the Brazilian market, especially in the automobile and auto parts sector. Moreover, it was aimed at the telecommunications and electronics sector (Barros 2020). 
The total received in this period was US\$ $13730 \mathrm{~m}$ (AEI 2021). In that sense, there is a shift in the search for resources towards the search for an investment market (Barros 2020).

The third phase was between 2013 and 2014, when investment flows were directed towards the financial sector to enhance bilateral trade and promote the internationalization of the renminbi (Cariello 2019). In 2014 the company China Construction Bank invested US\$720m dollars through the intermediary Bank Industrial and Commercial (AEI 2021).

Finally, the fourth phase was characterized by a new boom in power generation, yet this time directed towards transmission and distribution (led by the two big Chinese state companies: State Grid and Three Gorges). By the end of this period, the increase in transportation infrastructure projects stood out. Among them, ports and railways in strategic regions aimed at reducing the logistics costs of Brazilian trade (Barros 2020).

If we focus on the destination of Chinese FDI, we can identify approximately ten priority sectors, specified in Figure 3 below:

Figure 3. Main sectors receiving Chinese FDI (2004-2020)

$\$ 300.000$

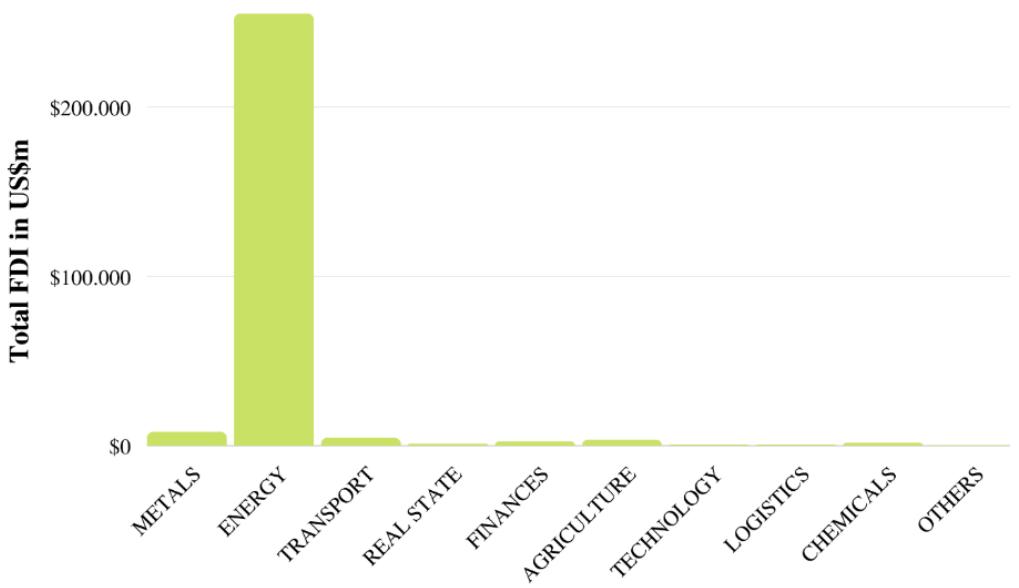

Source: Elaborated by the authors with data obtained from the Central Bank of Brazil (2020) and AEI (2021).

As we can see in the previous graph, during the 2004-2019 period, the sector that received the most investment flows (92\%) was related to power generation. The reason does not lie only in the supply interests of China, but also in the needs of Brazil (Wu 2020), which has traditionally had a deficit in the energy system. In 2001, a generalized blackout exposed the deficiencies and vulnerability of a system dependent on hydroelectric energy and the general insufficiency of the country's generation and transmission systems, which also highlighted the poor interconnection between regional electricity grids (Cote 2014). Thus, the Asian giant became a key player in the construction of power transmission lines and substations for Brazil (Li, Gallagher and Mauzerall 2020) by means of capital inflow (through state companies such as State Grid). 
Here we can see how the investment pattern in the region responds to China's strategic energy security interest, in which Brazil occupies a priority place. To put it in perspective, in 2010 and 2016 (years that we have already indicated as the ones with the greatest expansion of FDI), of the total Chinese FDI flows in the country, the energy sector represented $88.1 \%$ and $85.9 \%$ of the total share, respectively (AEI 2021).

Regarding the geographical distribution of investment flows, the report of the China-Brazil Business Council (2013) sponsored by the Inter-American Development Bank affirms that the majority of Chinese investment flows are concentrated in the south-eastern region of Brazil, namely the states of São Paulo, Rio de Janeiro and Minas Gerais. These states are the ones that most attract Chinese investment. This is due to the presence of important energy and mining operations in that region (CBBC 2013).

As we have seen, Chinese FDI in Brazil is concentrated in hydrocarbons, in which crude oil and gas stand out, as well as hydropower (generation and transmission of energy). In that sense, the clear direction of Chinese FDI towards the energy sector rests on the existing gaps between energy production and consumption in China, the result of the accelerated industrialization processes in conjunction with the growth of construction and transportation in the Asian country (Rubiolo 2010). On the other hand, it also targets a particularly sensitive sector for Brazil's economic development (such as electricity and infrastructure) (Wu 2020).

Moreover, as discussed below, it is possible to observe an articulation between trade and investment in that China seeks to use investment to have greater control over its suppliers of imported energy resources. Along the same lines, Javier Vadell (2018) argues that Brazil is China's main commercial partner in the region, the second destination for credits, and the first destination for its FDI in Latin America.

But how is the economic statecraft implemented? In the realization of their strategic interests, Chinese state companies play a fundamental role since they are articulated with the government's objectives. Next, we will address the main characteristics of these companies and analyse their participation in the FDI that China carries out in Brazil.

\section{(ii) State-owned companies and Chinese FDI in Brazil}

In order to deepen the reasons that drive China to disburse part of its world FDI flows in Latin America, it is necessary to analyse certain characteristics of the Chinese public sector as well as its predominant role in the economy.

The structure that surrounds political power in China is materialised through the Chinese Communist Party, which consists of a complex interrelation of institutions. Among them we can find the Central Committee, the Central Military Commission, the Standing Committee of the Politburo, the National People's Congress (NPC), the People's Liberation Army and, finally, the Central People's Government. These institutions are the ones that design the strategies to be implemented in the country in the short, medium and long term (Busilli 2017).

Delving further into the composition of the Chinese public sector, both the state council and the National Development and Reform Commission (NDRC) are in charge of the formulation, implementation and evaluation of long-term strategies. This shows that 
the Chinese government has a solid structure that ensures the achievement of its stated objectives (Busilli 2017).

In addition to these institutions, we can find a body that controls and brings together the main state companies. This body is the SASAC: State-Owned Assets Supervision and Administration Commission. In it, each business group is frequently connected through shared ownership and contractual alliances with other groups in the same industry or complementary ones. Regarding their internal organization, we can highlight that the top executives of large state-owned companies simultaneously hold important positions in the government and in the communist party (Curtis and Li-Wen 2013).

So, what do we understand by state companies? Enrique Dussel Peters (2015) refers to them as legal entities created by a central government. In China, however, state-owned enterprises also include entities which local governments control or invest in. According to the author, we can find three types of state-owned enterprises in China. The first are enterprises that are wholly state-owned or $100 \%$ financed by the public sector. The second type are state holdings, that is, companies in which the public sector owns a majority of the shares. Finally, the third type are those companies with shares that are owned by the state, in which the public sector, formally, does not have decisive power (Dussel Peters 2015).

To provide an analysis of the actions of Chinese companies that have invested in Brazil, it is noted that the extraction and distribution of hydrocarbons, as well as the production of energy, is an activity of state companies. Four of these state companies are identified in particular, such as those that control the sector: Sinopec, the China National Petroleum Corporation (CNPC), Sinochem, and CNOOC. Each of them presents different characteristics according to the origin and the commercial strategy adopted. For example, CNCP is usually devoted to performing extraction activities, Sinopec specializes in processing and distribution, and CNOOC, in the exploitation of subsea oil wells (ECLAC 2010). Another one of the large state-owned companies in the energy sector is the State Grid Corporation of China (SGCC), the world's largest electricity company and responsible for much of the operation of the country's electricity grid. The SGCC's main business is to build and operate power grids (Barros 2020; Cariello 2019).

In the case of Brazil, FDI is generally carried out through the acquisitions of assets of transnational or national companies, or through partnerships with Brazilian state-owned companies and other transnational groups (Dussel Peters 2014; Barros 2020). In the oil sector, for example, FDI is carried out through the acquisitions of private companies with ongoing production and the strategic alliance with Western companies. Examples thereof are the mergers and acquisitions in the extraction area of Sinopec and Sinochem for US\$7.1b and US\$3.07b, respectively. Both companies have established alliances with European companies: Sinopec with Repsol and Sinochem with Statoil (ECLAC 2010).

Responding to our research object, the following table details the companies that have invested in the energy sector during the period 2004-2020. What we can highlight is that all of them are state companies. The information provided will be of special importance to identify which subsectors the investment was destined to and which state companies carried it out. 
Table 1. FDI flows by Chinese state-owned companies in the energy sector (2004-2020)

\begin{tabular}{|c|c|c|c|}
\hline YEAR & ENTERPRISE & SUBSECTOR & TOTAL FDI IN MILLION US DOLLARS \\
\hline 2004 & - & - & - \\
\hline 2005 & CITIC & COAL & US\$ 240 \\
\hline 2006 & SINOPEC & GAS & US\$ 1290 \\
\hline 2007 & - & - & - \\
\hline 2008 & - & - & - \\
\hline 2009 & - & - & - \\
\hline \multirow{3}{*}{2010} & SINOCHEM & OIL & US\$ 3070 \\
\hline & STATE GRID & ENERGY & US\$ 1720 \\
\hline & SINOPEC & OIL & US\$ 7100 \\
\hline 2011 & SINOPEC & OIL & US\$ 4800 \\
\hline 2012 & STATE GRID & ENERGY & US\$ 1490 \\
\hline \multirow{2}{*}{2013} & CNOOC y CNPC & OIL & US\$ 1400 \\
\hline & THREE GORGES & ENERGY & US\$ 4380 \\
\hline \multirow{3}{*}{2014} & STATE GRID & ENERGY & US\$ 970 \\
\hline & THREE GORGES & ENERGY & US\$ 390 \\
\hline & THREE GORGES & ALTERNATIVE & US\$ 140 \\
\hline \multirow{4}{*}{2015} & BYD & ENERGY & US\$ 100 \\
\hline & STATE GRID & ENERGY & US\$ 2200 \\
\hline & THREE GORGES & ENERGY & US\$ 490 \\
\hline & ICBC & OIL & US\$ 2000 \\
\hline \multirow{5}{*}{2016} & THREE GORGES & ENERGY & US\$ 3660 \\
\hline & STATE GRID & ENERGY & US\$ 5580 \\
\hline & $\mathrm{CIC}$ & GAS & US\$ 1500 \\
\hline & THREE GORGES & ENERGY & US\$ 1200 \\
\hline & SINOMACH & ENERGY & US\$ 1500 \\
\hline \multirow{3}{*}{2017} & STATE POWER INVESTMENT & ENERGY & US\$ 2260 \\
\hline & CNPC & OIL & US\$ 120 \\
\hline & STATE GRID & ENERGY & US\$ 3440 \\
\hline \multirow{2}{*}{2018} & SHANDONG KERUI & GAS & US\$ 530 \\
\hline & THREE GORGES & ENERGY & US\$ 190 \\
\hline \multirow{2}{*}{2019} & CHINA GENERAL NUCLEAR & ALTERNATIVE & US\$ 1810 \\
\hline & CNPC, CNOOC & OIL & US\$ 1900 \\
\hline 2020 & STATE POWER INVESTMENT & GAS & US\$260 \\
\hline
\end{tabular}

Source: Elaborated by the authors based on data obtained from AEI (2021) 
In Table 1, we can see that three large state companies have been responsible for the main Chinese investment flows in Brazil: State Grid, Sinopec and Sinochem. Indeed, they have had a majority stake in the highest investments of the analysed period. In the year of 2010, State Grid, Sinopec and Sinochem made investments worth US\$11 890m. In 2016, State Grid invested US\$5.58b.

Compared to 2010, the peak recorded occurred due to important acquisitions such as the purchase, by Sinochem, of US\$3.07b of Brazilian assets in the Norwegian oil company Statoil. On the other hand, the purchase of seven power transmission plants by the largest electricity company in China, State Grid, was accounted for US\$1720m (Infobae, October 14, 2017). However, the most significant operation was conducted by Sinopec, by acquiring 40\% of Repsol Brasil's assets for a value of US\$ 7.1b dollars (Repsol, October 1, 2010).

In 2016, when the highest Chinese investments of the entire period were recorded, State Grid carried out an investment of US\$5.58b from the Brazilian power company CPFL. During the BRICS summit in September 2017, it received authorization from the Brazilian government to complete its transmission line project valued at US\$3440m, connecting the new Belo Monte hydroelectric plant, in the Brazilian state of Pará, with the main urban centres in the south of the country (Ellis 2017). On the other hand, the China Three Gorges Corp. invested US $\$ 1.2 b$ to acquire the Brazilian assets from Duke Energy. It also bought a thirty-year franchise for two large hydroelectric plants for US $\$ 3660 \mathrm{~m}$ (Kynge 2017).

As we have seen in the previous table, the hydrocarbon subsector (oil, gas, and coal) represented $42,6 \%$ of the total amount invested, while the electric energy sector registered $53,9 \%$ (mainly in hydroelectric plants, generation plants, and transmission of energy). At the end of that period, there was a greater diversification of FDI in the sector towards clean energy projects (Barros 2020; Wu 2020). In that sense, the Chinese company CGN stands out. This company acquired two solar energy parks and another wind farm in 2019, in the northeast region of Brazil (América Economía, June 25, 2019).

Secondly, state-owned companies (among which State Grid, Sinopec and Sinochem stand out) are responsible for all the investment flows registered in the sector. In other words, they generate the largest Chinese FDI flows to Brazil.

Given the strategic nature of the association, the political sphere is an important axis in the bilateral relationship. At this point, concerns about Chinese interests in Brazil gained relevance with the arrival of Jair Bolsonaro to the presidency. In 2018, he accused Beijing of 'buying Brazil' and criticized the Chinese political regime (Frenkel 2018). Indeed, low political harmony affected Chinese FDI in Brazil: while in 2017 investment flows reached US $\$ 8620 \mathrm{~m}$, in 2018 and 2019 they fell drastically to 1790 and to US $\$ 4610 \mathrm{~m}$, respectively (AEI 2021). In terms of economic diplomacy, China sent a clear message to Brazil by drastically reducing capital to the country, which was now hostile. In 2019 and within the framework of President Bolsonaro's official visit to Beijing, the president qualified his statements, showing the intention to restore harmony in bilateral relations, by affirming that 'a considerable part of Brazil needs China, and China also needs Brazil' (El País, October 25, 2019). 
(iii) Linking trade flows in FDI

In the commercial sphere and in a few years, China has emerged as one of the main partners of a large part of the countries of the region. In many cases, it has even displaced traditional regional trading partners, such as the United States. This assumption is in line with authors such as Wigell and Soliz Landivar (2019), Wise and Chonn Ching (2018) and Wei Liang (2019), who highlight the high concentration of Latin American exports to China in primary sectors of the economy, mainly extractive (oil, gas and minerals) and agriculture.

According to Pieterse (2011), China has become a new centre for an increasingly peripheral Latin America. For the author, there are three elements that define the patterns of this relationship. The first is the economic compatibility of the Latin American region (as an exporter of commodities) and China (as an exporter of manufactured goods and capital). The second, a complementarity that rests on an economic asymmetry and interdependent bilateral trade. The third is Latin America's place in the Chinese development project (which includes issues such as the Taiwan question and the Chinese territorial integrity; issues related to human rights and non-intervention in internal issues of each state; and the support of the region upon Chinese entry to the WTO). As will be seen below, Brazil responds to this pattern, since China has been its main trading partner since 2012 (ECLAC 2013).

Figure 4. Brazilian exports to China. Brazilian imports of Chinese origin (2003-2020).

$\$ 75.000 .000 .000$

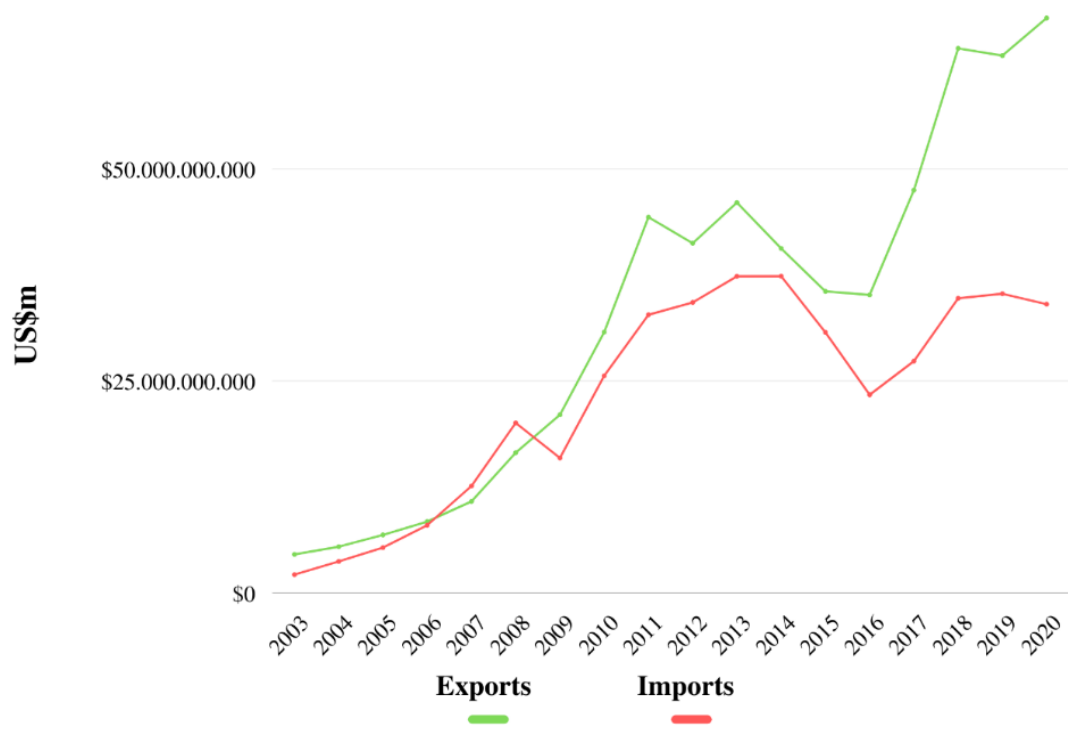

Source: Elaborated by the author with data obtained from Ministry of Economy (2021) 
Figure 4 above shows us that bilateral trade experienced exponential growth as of 2004. As can be seen, following the contraction generated by a slowdown and recession period in the Brazilian economy from 2013 to 2016, a growing trend was observed, both in exports and imports. In 2013, a year after being categorized as an integral strategic partnership', Brazilian exports to China reached US\$46 026m dollars, while imports from the Asian giant amounted to US\$ 37 304m. From then until 2016 (largely due to the recession of the Brazilian economy), exports and imports fell, despite Brazil maintaining its trade balance surplus. As of 2018, exports grew reaching record figures, largely motivated by the trade war between China and the United States, with exports to China worth US\$64 $206 \mathrm{~m}$ dollars and imports US\$34 730m, translating into a surplus of US\$29 476m dollars. In 2020, Brazilian exports rose to US\$67 788m and imports, US\$34 041, yielding a trade balance of US\$33 747m dollars (the highest number recorded throughout the entire study period).

Now, if we analyse the composition of Brazilian exports to China, we can see a growing share of the primary sector in total exports. In 2004, Brazil had more diversified exports to China, with a share of soybeans of $29,8 \%$, and an iron ore of $20,5 \%$. As the study period developed, a progressive concentration of exports in few products was observed, as well as a sustained growth in exports (Ministry of Economy 2021). In 2020, when Brazil registered a historical surplus, soybeans amounted to $30,8 \%$, iron ore to $27,3 \%$, and crude oil to $16,7 \%$; all these combined represented 74,9\% of total exports (Ministry of Economy 2021).

Brazilian imports from China, on the other hand, are characterized by being highly diversified and belonging to the category of manufactures. Four items stand out due to their growing importance. Between 2003-2020, 29,6\% of Brazilian imports from China were 'electrical telephony devices', followed by 'manufactured industrial inputs' $(27,1 \%)$, and by 'parts and accessories for capital goods', accounting for $24,8 \%$ of the total amount. Ranked fourth encompassing an $18,6 \%$ and linked to Brazilian exports to China is the 'drilling or exploitation platforms' (Ministry of Economy 2021). This is related to the expansion of the FDI in the energy sector. By securing supply channels, China achieves a dual purpose: ensuring food security and energy security.

Bilateral trade reflects a centre-periphery type structure and raises important questions about the possibilities of reprimarisation since China positioned itself as Brazil's main trading partner in 2012. In other words, the products most exported by Brazil, one of the most industrialized economies in the region, are primary in nature. On the other hand, to highlight dependency patterns, Brazil had a surplus in its trade balance of US\$50 941b dollars in 2020, of which China was responsible for $66,2 \%$ of the total amount (US\$33 741b) (Ministry of Economy 2021). This shows that Brazil not only reprimarised its export basket in its exchanges with China, but also that China is responsible for a large part of the favourable balances of Brazil's trade balance after becoming its first trading partner. In terms of economic diplomacy, the restriction or drop in exports (sticks) would directly affect the growth of the Brazilian economy. 
The data analysed shows a growing interest of China in the commodity trade with Brazil. In it, Beijing manages to stock up on raw materials (such as soybeans) and natural resources (iron ore and crude oil) that it needs to continue to foster its development model. In this regard, FDI has played a main role: controlling the supply chains of products exported to China (investments in agro-food) and facilitating transportation (infrastructure investments).

In the most recent periods, FDI has been oriented towards energy transmission, which contributes to improving Brazil's productivity rates by introducing technical improvements in its energy system. That way, China not only has a stake in the production and transportation of the goods it imports, but also plays a fundamental role in one of Brazil's strategic areas: its energy sector.

\section{Final thoughts}

Latin America occupies a strategic place for China with the strengthening of its energy and food security, as well as in the internationalization strategy of Chinese companies and the search for profitable markets - two of the country's major objectives.

As one of the most important economies in Latin America, Brazil is a priority within the Chinese strategy for the region. Besides, although the links obey similar logics, China and Brazil's bilateral relationship is more complex. The relaunch of the strategic relationship in 2004 demonstrated not only an economic rapprochement, but also a strong political harmony between the two countries. Under Lula's presidency, Brazil projected itself as an emerging power, demanding a more active role in international society. The newly elected president shared the perspective that the country was ready to become a global player. In this vein, China was strategic for Brazilian foreign policy, not only due to the increase in trade and investment flows, but also for being an ally in the request for revision of global international organizations and in terms of the demand for greater shares of power.

China consolidated its presence in the South American country, articulating trade and investment in order to supply itself with the raw materials it needed to feed a growing population and a growing economic system. It did so through promoting trade and by sourcing commodities such as soybeans, iron ore and crude oil. At the same time, Chinese FDI in Brazil is led by Chinese state-owned companies and follows a double logic: specifying strategic interests and seeking profitable markets. Given the objective of the work, we could observe that in a first phase, the investment flows were directed to the sources of supply of food and hydrocarbons. In a later phase, FDI tried to explore the Brazilian market in search of more profitable opportunities such as the automobile, telecommunications, and auto parts sector. The third phase coincided with the strengthening of bilateral ties and the launch of the Comprehensive Strategic Association in 2014, when Chinese FDI opted for the financial sector in order to facilitate loans for the supply of raw materials. 
Since 2014, there has been a return investing in the energy sector, but this time it is aimed at the transmission and distribution of local energy, as well as at transport infrastructure projects. Updating and developing both sectors contributes to reducing costs and optimizing the production and transportation time of those products exported to China. On the other hand, Brazil's dependence on Chinese capital increases progressively in sectors where it shows serious deficiencies, such as energy and infrastructure. This pattern is reinforced if we observe that China has become Brazil's first trading partner since 2012 and has a trade surplus that reached record figures in 2018, 2019 and 2020.

Finally, and taking up the complexity of the bilateral relationship in question, political harmony has set the pace of rapprochement between the two countries. Even though in the governments of Luiz Inácio Lula da Silva, Dilma Rousseff, and Michel Temer the strategic association was strengthened, since the administration of Jair Bolsonaro these bilateral ties have become more tense. This is reflected in the economic rationale as well. China continues to maintain high rates of trade with Brazil. Indeed, it has reached record figures since 2018, which shows surplus results for the South American country. In that sense, the pattern of trade not only represents a return to the traditional centre-periphery models where Brazil specialized in exports of primary products, but also, on the other hand, increases its dependence on China. Regarding investments, the scenario is different. There is a decrease both in capital flows and in the number of projects that shows that Chinese companies are cautious in betting on the short- and medium-term investments in Brazil. Likewise, priority sectors such as power generation and distribution represent sensitive areas for the security of the host country. In this vein, the logics of economic statecraft are strengthened because these same incentives can eventually become "sticks" since Chinese companies can use them to control, limit, interrupt or impose conditions on the provision of critical infrastructure goods and services for Brazil. Thus, as China is Brazil's first trading partner, as well as its second investor, dependency dynamics are reinforced.

Thus, amidst an economic and health crisis and in light of a bilateral relationship with low political harmony, Brazil appears to depend more and more on China, both in trade and in investment. Looking ahead, in the post-pandemic scenario, the challenge lies in balancing both sectors to launch an economic recovery, and on that note, China seems less vulnerable than the western powers.

\section{Notes}

1 Sinopec, in Brazil, and CNOOC, in Argentina. As we can see, hydrocarbons, directly linked to Beijing's energy security, represented the most important FDI sector. On the other hand, several Chinese companies arrived in Latin America or substantially strengthened their participation in 2010: State Grid in the electricity sector, Chery in the automotive sector and Chinalco in the mining sector (ECLAC 2013).

2 The United States concentrated its FDI on oil and gas extraction, the automotive industry, food production, the telecommunications sector, and sectors related to energy production and the chemical sector. The Netherlands, for its part, was interested in the telecommunications, food and automotive sectors. The case of France is similar to the aforementioned ones: it invests in the automotive sector, telecommunications, the food industry, the chemical sector, but mainly in the production and distribution of electrical energy. In fourth and last place is Germany, whose FDI is mainly directed to the automotive sector (ECLAC 2019). 


\section{References}

Abeliansky, A. L and I Martínez-Zarzoso. 2019. 'The Relationship between the Chinese "Going Out" Strategy and International Trade.' Economics: The Open-Access, Open-Assessment E-Journal 13 (1):1-18.

American Enterprise Institute (AEI). 2021. China Investment Tracker. AEI, Washington. [Online] At https://www.aei.org/china-global-investment-tracker/ [Accessed on 20 February 2021].

Latin American Integration Association (ALADI). 2020. Database. ALADI, Montevideo. [Online] At http://www.aladi.org/sitioaladi/ [Accessed on 20 February 2021].

Altemani de Oliveira, H. 2006. 'China-Brazil: perspectives for South-South cooperation.' New Society [online] 203(1): 138-147. At https://nuso.org/articulo/china-brasil-perspectivas-de-cooperacion-sur-sur/ [Accessed on 5 January 2021].

Baldwin, D. 1985. Economic Statecraft. New York: Princeton University Press.

Barros Torres, G. 2020. 'Chinese Foreign Direct Investment in Brazil: Evolution, trends and concerns over critical infrastructure.' Institutional Repository at Pontifical Catholic University Argentina. Faculty of Social Sciences. Department of Political Science and International Relations 31(1): 17-36.

Bayne, N. and Woolcock, S. 2017. The New Economic Diplomacy. New York: Routledge.

Bernal-Meza, R. and Li X. 2020. China-Latin America Relations in the 21st Century. The Dual Complexities of Opportunities and Challenges. Boston: Palgrave.

Berridge, G. R. and James A. 2003. A Dictionary of Diplomacy. London: Palgrave.

Broadman, H. G. 2007. 'Africa's silk road: China and India’s new economic frontier.' World Bank [online]. At https://openknowledge.worldbank.org/bitstream/handle/10986/7186/378950Africas0silk0road01PUBLIC1.pdf? sequence=1\&isAllowed=y. [Accessed on 28 February 2021]

Busilli, V. 2017. 'Characteristics and geographical distribution of Chinese FDI in Argentina and its evolution over time (2005-2015).' Oviedo, Eduardo (Comp.). Investments from China, Korea, Japan and Argentina: General Analysis and Case Studies. UNR Editora: Rosario.

Busilli, V. 2019. 'The Chinese presence in the Southern Cone: Strategic relations and commercial ties with Argentina and Brazil.' Studia Politicae 49(1): 77-109.

Cariello, Tulio. 2019. 'The Brazilian framework in a global perspective, Chinese Investments in Brazil (2018).' Brazil-China Business Council [Online] At https://shortest.link/vdG [Accessed on 28 January 2021].

China-Brazil Business Council (CBBC). 2013. Chinese Investments in Brazil from 2007-2012: A review of recent trends. CBBC, Rio de Janeiro [online]. At http://www.cebc.org.br/sites/default/files/ pesquisa_investimentos_chineses_2007-2012_-_ingles_1.pdf [Accessed on 28 January 2021].

Chen, W. and Tang H. 2014. 'The Dragon Is Flying West: Micro-Level Evidence of Chinese Outward Direct Investment.' HKIMR Working Paper No.1 4 [online]. At https://www.mitpressjournals.org/ doi/pdf/10.1162/ADEV_a_00032.

Central Bank of Brazil. 2020. Database. Central Bank of Brazil, Brasilia. At https://www.bcb.gov.br/ en [Accessed on 20 February 2021].

Cote, C. (2014). 'State Grid's Bold Leap: Chinese Investment in Brazil's Transmission Sector.' In Margaret Myers and Lisa Viscidi (eds), Navigating risk in Brazil's energy sector: the Chinese approach. Interamerican Dialogue, pp. 18-25. 
Dussel Peters, E. 2014. China's foreign direct investment in Latin America: 10 case studies. Federal District: National Autonomous University of Mexico.

Dussell Peters, E. 2015. 'The omnipresence of China's public sector and its relationship with Latin America and the Caribbean. Nueva Sociedad Magazine 34-44. [Online] At https://nuso.org/revista/259/el-desembarco-chino-en-america-latina/ [Accessed on 20 February 2021].

Economic Commission for Latin America and the Caribbean (ECLAC). 2005. Panorama of the International Insertion of Latin America and the Caribbean 2004: 2005 trends. ECLAC, El Salvador. [Online] At https://repositorio.cepal.org/handle/11362/1163 [Accessed on 10 January 2021].

Economic Commission for Latin America and the Caribbean (ECLAC). 2010. The People's Republic of China and Latin America and the Caribbean: towards a strategic relationship. ECLAC, El Salvador. [Online] At

https://repositorio.cepal.org/bitstream/handle/11362/2956/1/RP_China_America_Latina_Caribe. pdf [Accessed on 10 January 2021].

Economic Commission for Latin America and the Caribbean (ECLAC). 2011. Foreign Direct Investment in Latin America and the Caribbean 2010. ECLAC, El Salvador. [Online] At https://www.cepal. org/es/publicaciones/1141-la-inversion-extranjera-directa-america-latina-caribe-2010 [Accessed on 10 January 2021].

Economic Commission for Latin America and the Caribbean (ECLAC). 2013. Chinese foreign direct investment in Latin America and the Caribbean: China-Latin America cross-council taskforce. Working document. ECLAC, El Salvador. [Online] At https://www.cepal.org/en/publications/35927-chinese-foreign-direct-investment-latin-america-and-caribbean-china-latin-america [Accessed on 12 January 2021].

Economic Commission for Latin America and the Caribbean (ECLAC). 2018. Foreign investment in Latin America and the Caribbean 2018. ECLAC, El Salvador. [Online] At https://www.cepal.org/es/ publicaciones/43689-la-inversion-extranjera-directa-america-latina-caribe-2018 [Accessed on 12 January 2021].

Economic Commission for Latin America and the Caribbean (ECLAC). 2019. Foreign Direct Investment in Latin America and the Caribbean 2019. ECLAC, El Salvador. [Online] At https://www.cepal. org/es/publicaciones/44697-la-inversion-extranjera-directa-america-latina-caribe-2019 [Accessed on 15 January 2021].

Frenkel, A. 2018. 'The world according to Bolsonaro. Brazil's new foreign policy'. Nueva Sociedad. [Online] At https://www.nuso.org/articulo/el-mundo-segun-bolsonaro/ [Accessed on 05 February 2021].

Gilpin, R. 1990. The political economy of international relations. Buenos Aires: Latin American Publishing Group.

Goldstein, A. 2005. Rising to the Challenge. China's Grand Strategy. Stanford: Stanford University Press.

Greitens, S. 2013. 'US-China relations and America's alliances in Asia.' Brooking Opinion [Online]. At https://www.brookings.edu/opinions/u-s-china-relations-and-americas-alliances-in-asia/ [Accessed on 18 January 2021].

Hill, C. 2016. Foreign Policy in the Twenty Fist Century. Basingstoke: Palgrave Macmillan.

International Monetary Fund (IMF). 2004. Balance of Payments Manual Review, Fifth Edition (Annotated Review). IMF, Washington, D.C., April. 
Johnson, C. 2016. 'President Xi Jinping's “Belt and Road” Initiative'. Center for Strategic and International Studies [Online]. At https://www.csis.org/analysis/president-xi-jinping\%E2\%80\%99s-beltand-road-initiative [Accessed on 18 January 2021].

Li, Y. 2017. 'Belt and Road: A Logic Behind the Myth. In China’s Belt and Road: a Game Changer?' In A. Amighini (eds), China's Belt and Road: A Game Changer?. Milano: Edizioni Epoké, pp. 13-34.

Li, Y. and Taube M. 2019. 'How China's Silk Road Initiative Is Changing the Global Economic Landscape.' Routledge Studies in the Growth Economies of Asia No. 142. New York: Routledge.

Li, Z, K Gallagher and D. Mauzerall. 2020. 'China's Global Power: Estimating Chinese Foreign Direct Investment in the Electric Power Sector'. Energy Policy, 136 (1).

Liang, W. 2019. 'Pulling the Region into its Orbit? China's Economic Statecraft in Latin America' Journal of Chinese Political Science 24 (1): 433-449.

Lin, L. and C Milhaup. 2013. 'Large Chinese Business Groups: Understanding the Mechanisms of State Capitalism in China.' Chilean Journal of Law 4 (3): 801-858. [Online] At https://doi. org/10.4067/s0718-34372013000300004 [Accessed on 25 January 2021].

Medeiros, E. 2009. 'China's International Behavior. Activism, Opportunism, and Diversification.' Santa Monica, CA: RAND Corporation.

Ministry of Economy of Brazil. 2021. Comex Stat Database [Online]. Ministry of Economy, Brasilia. [Accessed on 20 February 2021] At http://comexstat.mdic.gov.br/pt/home.

Myers, M. and L Viscidi. 2014. 'Navigating Risk in Brazil's Energy Sector: the Chinese Approach.' The Dialogue [Online] At https://www.thedialogue.org/wp-content/uploads/2015/04/IAD9713_ ChinaBrazilEnergy_FINAL.pdf [Accessed on 25 January 2021]

Norris, W. 2010. Economic Statecraft with Chinese Characteristics: The Use of Commercial Actors in China's Grand Strategy. New York: Princeton University Press.

Oviedo, D. 2005. China expanding. Córdoba: Editorial of the Catholic University of Córdoba.

Orozco Suárez, C. R. 2018. 'The Role of Chinese FDI in Latin America and the Caribbean: SouthSouth Cooperation?' European papers magazine [online] 31 (1): 57-67. At https://revistas.ucm.es/ index.php/PADE/article/view/61489 [Accessed on 4 February 2021].

Pieterse, J. N. 2011. 'Global Rebalancing: Crisis and the East-South Turn.' Development and Change 42(1): 22-48.

Ramón-Berjano, C, J Malena and M Velloso. 2015. 'China's relationship with Latin America and Argentina. Working Documents No 96'. Argentine Council for International Relations [online]. At http://www.cari.org.ar/pdf/dt96.pdf [Accessed on 23 February 2021].

Rana, K. 2013. 'Economic Diplomacy: What might best serve a Developing Country?' Int. J. Diplomacy and Economy 3/4 (1): 232-247.

Reilly, J. 2013. China's economic statecraft: turning wealth into power. Sidney: Lowy Institute for International Policy.

Rubiolo, M F. 2010. 'Energy security in China's foreign policy in the 21st century'. Revista CONfines [online] 6 (11):59-83. At http://www.scielo.org.mx/scielo.php?script=sci_arttext\&pid=S1870-35692010000100004 [Accessed on 16 January 2021].

Shan, W. and S Zhang. 2011. 'The Treaty of Lisbon: Half Way toward a Common Investment Policy.' The European Journal of International Law 21 (4): 1049-1073. 
Svampa, M and A Slipak. 2015. 'China in Latin America: From the Commodities Consensus to the Beijing Consensus.' Ensambles magazine year 2, 3 (1): 34-63.

Vadell, J. 2018. China's Economic and Geopolitical Expansion Does Not Know XXI. Belo Horizonte: Editorial PUC Minas.

Vigevani, T and G Cepaluni. 2007. 'A Foreign Policy of Lula Da Silva: A Strategy of Autonomy for Diversification.' International Context 29 (2): 273-335.

Vigevani, T and G Cepaluni. 2009. Brazilian foreign policy. The search for autonomy, from Sarney to Lula. São Paulo: UNESP Publishing Foundation.

Wachholz, L. 2019. 'New rules for Chinese Investment in the World and its Possible Effects for Brazil.' In Menezes, E. J. S, China by Brazilian sinologists: Views on economics, culture and society. Rio de Janeiro: Batel.

Wang, H. 2016. 'A deeper look at China’s “Going Out Strategy.” Center for International Governance Innovation 1-4. [Online] At https://www.cigionline.org/publications/deeper-look-chinas-going-out-policy [Accessed on 13 February 2021].

Wigell, M and A Soliz Landivar. 2019. 'China's Economic Statecraft in Latin America: Geostrategic Implications for the United States.' In M Wigell, S Scholvin and M Aaltola (eds.), Geo-Economics and Power Politics in the 21st Century: The Revival of Economic Statecraft. London: Routledge.

Wise, C and V Chonn Ching. 2017. 'Conceptualizing China - Latin America Relations in the Twenty-First Century: the Boom, the Bust, and the Aftermath.' The Pacific Review 31 (5): 553-572.

$\mathrm{Wu}, \mathrm{W}$. 2019. Chinese oil enterprises in Latin America. Corporate Social Responsibility. New York: Palgrave.

Zhang, X. 2017. 'Conceptualizing China's economic diplomacy: conversion between wealth and power.' In Bayne, Nicholas and S Woolcock. (eds), The New Economic Diplomacy. 4th edition. New York: Routledge, pp. 138-151.

Zhao, K. 2011. 'The Rise of Economic Diplomacy: Substances, Institutions and Trends.' Jiao Xue Yu Yan Jiu (1).

America Economy. 2019. 'China CGN starts up three renewable energy plants in Brazil acquired from Enel for US \$ 660M.' 25 June. [Online]. At https://www.americaeconomia.com/negocios-industrias/fusiones-adquisiciones/china-cgn-pone-en-marcha-tres-plantas-de-energia [Accessed on 3 March 2021].

BBC World. 2019. 'The Latin American countries that are part of the New China Silk Road.' April 26. [Online]. At https://www.bbc.com/mundo/noticias-america-latina-48071584 [Accessed on 5 March 2021].

Ellis, E. 2017. 'Washington should take note of China's advance in Brazil.' Chinese Dialogue, 2 November. [Online]. At https://dialogochino.net/es/comercio-y-inversiones-es/9762-washington-deberia-tomar-nota-del-avance-de-china-en-brasil/ [Accessed on 3 March 2021].

El País. 2019. 'Bolsonaro seals his reconciliation with China with investment proposals.' October [Online]. At https://elpais.com/internacional/2019/10/25/actualidad/1571966736_154441.html [Accessed on 27 February 2021]. 
Infobae. 2017. 'China's influence in Brazil that threatens the region: what are the multimillion-dollar investments in the South American giant.' 14 October. [Online]. At https://www.infobae.com/america/america-latina/2017/10/14/cuales-son-las-multimillonarias-investments-de-china-en-brasilque-already-surpass-the-las-Americans / [Accessed on 26 February 2021].

Kynge, J. 2017. 'China rescues Brazilian Infrastructure' Expansion [online]. 2 October. [Online]. At https://www.expansion.com/latinoamerica/iberoamericana-empresarial/2017/10/02/ 59d17040468aeb5b798b4576.html [Accessed on 10 March 2021].

Repsol. 2010. 'Sinopec, one of the world's leading Oil Companies, will invest more than $\$ 7.1$ billion.' 1 October. [Online]. At https://www.repsol.com/imagenes/global/es/repsol_brasil_sinopec_tcm1313752.pdf [Accessed on 15 February 2021].

\section{About the authors}

Virginia Soledad Busilli holds a BA Degree in International Relations from the 21st Century Business University in Córdoba, Argentina. She also holds a Master's Degree in Chinese Economy, Culture and Society from the Alcalá de Henares University in Madrid, Spain. She is currently a PhD candidate in Social Studies of Latin America at the National University of Córdoba in Córdoba, Argentina. She is a CIECS/CONICET (National Council for Scientific and Technical Research, Argentina) doctoral fellow, an Adjunct Professor at the Catholic University of Córdoba (UCC), and a member of the research project "Determinants and interests in international relations between South America and East Asia" at the UCC.

María Belén Jaime holds a Degree (BA) in International Relations from the Catholic University of Córdoba (UCC). She is a current member of the research project "Conditions and interests in international relations between South America and East Asia" at the UCC in Córdoba, Argentina. 


\title{
Investimentos chineses no Brasil: Diplomacia Econômica nas relações bilaterais
}

\begin{abstract}
Resumo: A República Popular da China consolidou seu status de grande potência e fortaleceu sua presença em diferentes regiões do planeta. Respondendo à sua estratégia de desenvolvimento econômico, o crescente vínculo de Pequim com a América Latina é parte da necessidade da China de garantir seu acesso a matérias-primas e recursos energéticos. Neste contexto e através da diplomacia econômica, a China tem fortalecido o comércio, empréstimos e investimentos na maioria dos países da região. O Brasil responde a este padrão de relacionamento, sendo um dos parceiros mais importantes da China na América Latina. O país é o primeiro destino de investimento do gigante asiático na região e em 2012 Pequim se tornou seu primeiro parceiro comercial. Este trabalho analisará a composição e a evolução do investimento estrangeiro direto (IED) chinês no Brasil no período entre 2004 e 2020. Para isso, estudaremos os principais projetos realizados, bem como as características das empresas chinesas (estatais ou não) que deles participaram, a fim de compreender as características mais importantes desse processo. Da mesma forma, analisaremos a articulação do IED com o fluxo comercial entre os dois países. Partiremos da premissa de que os investimentos chineses no Brasil estão diretamente ligados aos interesses estratégicos de Pequim e, ao mesmo tempo, guiados por lógicas de mercado que tentam maximizar os lucros. Nesta etapa, dentro do marco da 'estratégia de saída', as empresas estatais desempenham um papel fundamental.
\end{abstract}

Palavras-chave: América Latina, China, diplomacia econômica, IDE, interesses estratégicos.

Received on 17 July 2020, and approved for publication on 23 June 2021. 